\title{
WILT DISEASES OF TOMATO (Lycopersicum esculentum) AND CHILLI (Capsium annum) AND THEIR MANAGEMENT STRATEGIES: EMPHASIS ON THE STRATEGIES EMPLOYED IN SRI LANKA: A REVIEW
}

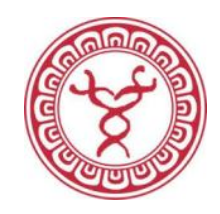

Sandani H. B. P. and Weerahewa H. L. D.

Department of Botany, The Open University of Sri Lanka, Nawala, Nugegoda

\begin{abstract}
Wilt is one of the major diseases causing economic losses in many crops. It is caused by infections of many bacterial (Ralstonia solanacearum), fungal (Fusarium spp., Vertcillium spp., Rhizoctonia spp., Sclerotium spp.), oomycete (Pythium spp., Phytophthora spp.) and viral (Tomato spotted wilt virus) pathogens. This review provides an overview on the control strategies used in other countries for the wilt disease in highly susceptible vegetable/fruit crops; tomato and chilli and make comparisons with Sri Lanka.

Many studies have been performed on the prevalence, severity, pathogenicity and the control of these infections in both crops worldwide. Wilt in tomato is caused mainly by Ralstonia solanacearum and Fusarium oxysporum and in chilli mainly by Fusarium oxysporum. Tomato bacterial wilt is successfully managed through usage of resistant cultivars, grafting, biological control agents, inducing host systemic resistance and integrated management. Tomato and chilli wilt caused by Fusarium sp. have been successfully controlled mainly through the application of chemicals and biological approaches such as systemic defense induction and the use of microbial antagonists.

In Sri Lanka, tomato wilt is reported as being the result of bacterial, fungal and viral infections which have been mainly controlled by the usage of resistant cultivars, physical measures and cultural practices. Chilli wilt in Sri Lanka has not been thoroughly studied yet. But application of fungicides has been an effective strategy for fungal wilts. Wilt threat of tomato and chilli in Sri Lanka has to be further studied for the proper management of these infections and for freeing tomato and chilli cultivations from the wilt disease.
\end{abstract}

Keywords: Chilli, Fusarium sp., Ralstonia solanacearum, Tomato, Wilt disease

*Corresponding author: E-mail: $\underline{\text { hlwee@ou.ac.lk }}$

Received date: 16/03/2018, Accepted date: 03/05/2018

https://orcid.org/0000-0002-2132-9951

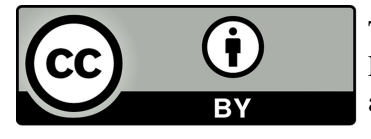

This is an open-access article distributed under the terms of the Creative Commons Attribution 4.0 International License, which permits unrestricted use, distribution and reproduction in any medium provided the original author and source are credited. 


\section{Introduction}

\section{Significance of tomato and chilli}

Tomato, used as a vegetable and chilli as a spice, owe a prominent place in a balanced diet. Tomato is a highly demanded, nutritive vegetable mainly in vegetarian diets throughout the world. It is also a good source of vitamins C and A and minerals such as $\mathrm{Fe}$ and $\mathrm{Cu}$ (Siemers, 1971). Tomato has a high demand as a fresh and as a processed product both in local and foreign markets.

Chilli plays a significant socio economic role worldwide due to its nutritional value, medicinal properties, industrial and ornamental properties. Chilli is in high demand as a good source of vitamins (A, B1, B2, B3, C and E), carotenoids and capsaicinoids. Tomato and chilli are two vital vegetable crops among Sri Lankan farmers due to its high economic returns and export potential.

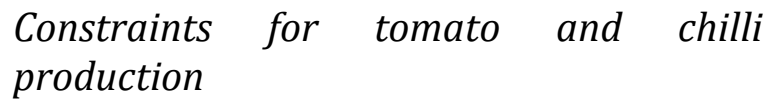

Commercial tomato and chilli production is hampered worldwide due to many biotic and abiotic stresses. Tomato is primarily vulnerable to economic losses due to postharvest damage caused by its highly perishable nature, inefficient postharvest handling procedures and consequences of preharvest diseases. Tomato is infected by various phytopathogens. Almost all the parts of the tomato plant are susceptible to many pathogenic infections at various growth stages. Anthracnose, blossom end rot, sunscald, early and late blight, septoria leaf spot, fusarium wilt, bacterial wilt, verticillium wilt, damping off, southern blight, powdery mildew, gray leaf spot, tomato spotted wilt virus, tobacco mosaic virus are the most common tomato fruit crop diseases around the world. Among these, tomato wilt is the most destructive disease causing much damage to tomato cultivations.

Constraints to commercial chilli production include both pre-harvest and postharvest damage caused by phytopathogens. Pre-harvest infections include wilt diseases, damping off, other fungal, bacterial and viral infections while the main postharvest damage of chilli is anthracnose caused by a fungal infection in addition to mechanical damage. Common pathogenic infections on chilli include anthracnose, bacterial leaf spot, bacterial soft rot, bacterial wilt, fusarium wilt, cercospora leaf spot, damping off, powdery mildew, verticillium wilt and various viral infections (Pea enation mosaic virus (PeMV), Tobacco etch virus (TEV), Tobacco mosaic virus (TMV)). Among them, wilt, damping off and anthracnose are the major diseases largely affecting commercial chilli production in Sri Lanka.

\section{Wilt disease}

Wilt is a plant disease that results from the infection of roots and vascular system of plants by several phytopathogenic fungi, bacteria, virus and nematodes. Infection of roots and vascular vessels hinder water transportation resulting in wilting of the stems and leaves. It was recorded that wilt is one of the major diseases causing the highest preharvest losses. 
Bacterial wilt disease is mainly caused by several bacterial species belonging to the genera Pseudomonas, Corynebacterium, Erwinia and Xanthomonas. Wilt disease is also caused by fungal pathogens such as Fusarium, Pythium, Phytophthora, Rhizoctonia, Sclerotium and the species Verticillium dahlia. The infected crops suffer from stunting, wilting, withering, chlorosis, necrosis and defoliation of plant parts which finally results in the death of the plant. Wilt infections cause huge economic loses in many solanaceous crops such as tomato (Solanum lycopersicon), potato (Solanum tuberosum), chilli (Capsicum annuum), tobacco (Nicotiana sp.), brinjol (Solanum melongena), cucumber (Cucumis sativus) and in banana (Musa sp.) in tropical, subtropical and temperate regions (Hartman \& Elphinstone, 1994).

\section{Wilt infections in tomato}

Tomato wilt is caused by several different phytopathogens. Wilt caused by Ralstonia solanacearum, Fusarium spp., Verticillium spp., Sclerotium spp. and Rhizoctonia spp. has been reported in tomato. Among them, bacterial wilt caused by Ralstonia solanacearum is identified as the greatest threat to tomato cultivations in Sri Lanka (Bandara, 1983; Ilankoon, 2001; Gunathilake et al., 2004).

\section{Bacterial wilt in tomato}

Bacterial wilt is known to occur mainly in the wet tropics, sub tropics and some warm temperate regions of the world such as China, Fiji, India, Indonesia, Papua New Guinea, Phillipines, Sri Lanka and Thailand (Persely, 1986). This can bring about the total destruction in tomato during rainy seasons. In Asia it is a serious infection in the lowland humid tropics and in the cooler tropical highlands, but not in the semi-arid tropics.

It is caused by the soil borne pathogen, Ralstonia solanacearum E.F.Smith, previously known as Pseudomonas solanacearum, a widespread pathogen of solanaceous hosts. The disease affects more than 200 plant species in over 35 50 families throughout the world including a wide range of crop plants, ornamentals and weeds (Kelman, 1953; Hayward, 1995). The major economic hosts include potato, tomato, eggplant, pepper, ginger, peanut, banana etc.

The primary source of this causal agent is the soil. The infection occurs through wounds in the root system caused by mechanical damages or root knot nematodes and pores via emerging lateral roots. Once the pathogen enters the host, it invades the xylem of the plant and disrupts water translocation resulting rapid wilting and death. Disease symptoms are said to appear four days after the infection (Ilankoon et al., 2001).

Diseased plants release large number of bacteria to the soil resulting infection of neighboring plants. $R$. solanacearum is known to spread within and between countries by soil, water and through latently infected planting materials. The spread of this causal agent is facilitated by cultural practices such as furrow irrigation, transplanting, pruning, hydroponics etc. In addition, high soil moisture and optimum temperature for the pathogen also favour disease development and dispersal (Kranz et al., 1997). 
Initial symptoms of bacterial wilt are visible on tomato foliage. The youngest leaves at the end of the branches wilt during the hottest part of the day. Gradually the entire plant may wilt and desiccate although dried leaves remain green, leading to general wilting and yellowing of foliage and eventually plant death. Another common symptom associated with this in the field is stunting of the plant. In addition, collapse of the stem may also be observed (Champoiseau $\&$ Momol, 2009) (Figure 1).

\section{Tomato bacterial wilt disease in Sri Lanka}

Even though bacterial wilt is one of the major obstacles in tomato production in Sri Lanka, there are only limited records on disease incidence, prevalence and remedies in Sri Lanka (Bandara, 1983; Bandara, 1984; Velupillai, 1986; Ilankoon et al., 2001; Gunathilake et al., 2004; Senarathna et al., 2012). These reports are on diversity, pathogenicity and biotype distribution of $R$. solanacearum and report grafting and varietal resistance as remedies for the disease.
Park \& Fernando, (1938) first reported the threat of bacterial wilt in tomato in the wet zone. A high incidence of bacterial wilt has been reported in Nuwara Eliya in 1986 in Sri Lanka (Vellupillai, 1986). The incidence of this disease is mainly reported from the mid and low country wet and intermediate zones in Sri Lanka as revealed by Kelaniyangoda, (1995). According to Abeygunawardana \& Siriwardana (1961), bacterial wilt was a limiting factor for the extension of potato in elevations below $1540 \mathrm{~m}$. It should be the same in case of tomato. Solanaceous crops such as chilli, eggplant, tomato and potato in Sri Lanka are susceptible to the bacterial wilt disease caused by $R$. solanacearum (Velupillai, 1986).

More detailed studies have been carried out on the bacterial wilt disease on potato in Sri Lanka (Velupillai, 1986), but not on tomato. In 1969, Senevirathne classified the bacterial wilt pathogen in Sri Lanka into three biovars using Hayward's (1964) biochemical classification. Gunawardana et al., (1980) detected $P$. solanacearum in several different hosts in

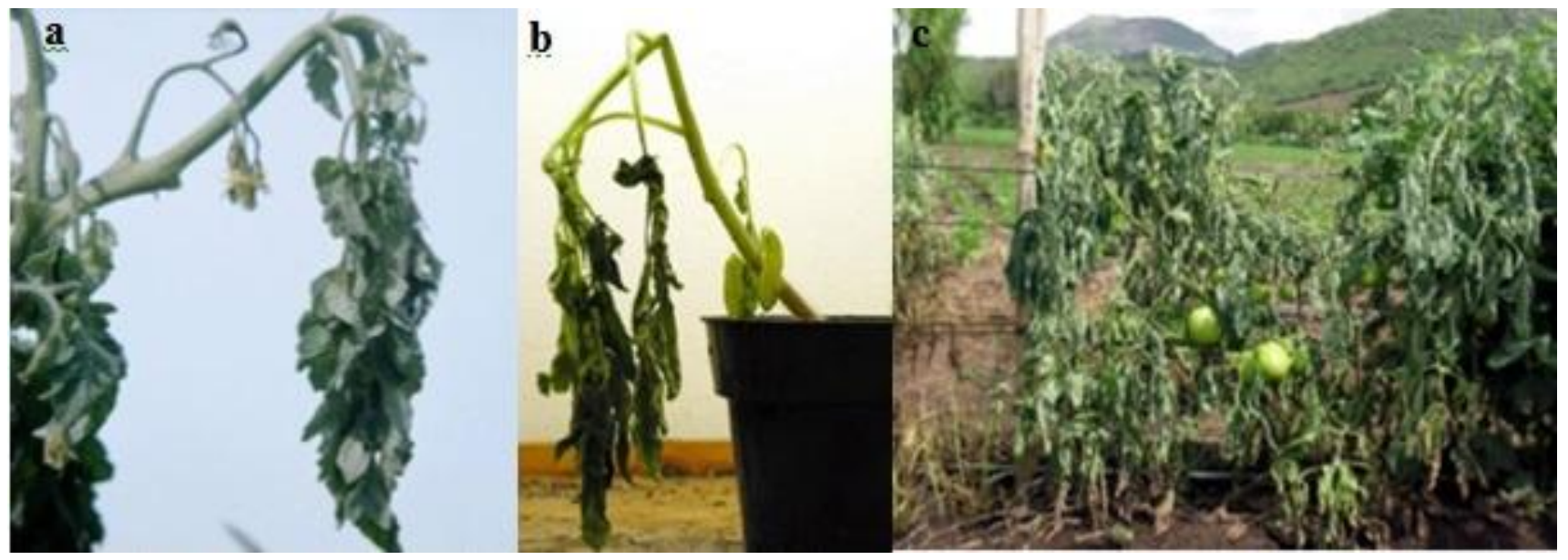

Figure1. Symptoms of bacterial wilt: a) wilting of young leaves b) collapsing of stem c) stunting of plants 
Sri Lanka including Anthurium andraeanum from Handessa (mid country), Curcuma domestica (turmeric) and Zingiber officinale (ginger) from Gampaha (low country), Phaseolus vulgaris (bush bean) and Psophocarpus terragonolobus (winged bean) from Gannoruwa (mid country), Croton hirtus, Hyptis suaveolens and Sesamum idicum (Gingelly) from coconut growing regions in Kurunegala (mid country). Also this was the first record of $R$. solanacearum on $A$. andraenum, $C$. hirtus, $R$. tetragonolobus, $C$. domestica and $M$. charantia (Gunawardana et al., 1980).

As reported by Gunathilake et al., (2004), sixteen of the selected $R$. solanacearum isolates were highly virulent while four were moderately virulent on the susceptible tomato variety Marglobe. According to that report, the pathogen shows a high genetic diversity in the Kandy, Matale and Monaragala districts. It was further reported that the isolate collected from Hanguranketha (Maoya) can be used for screening of existing tomato germplasm in Sri Lanka for bacterial wilt resistance since it has recorded the highest relative pathogenicity score value.

Bandara, (1983) studied the biotype distribution of the vascular wilt pathogen $R$. solanacearum in Sri Lanka. He detected the biotype 2 and 3 of $R$. solanacearum in Sri Lanka. Prior to that Senevirathne, (1969) had also reported the occurrence of the biotypes 2, 3 and 4 in the hill country of Sri Lanka. According to Bandara (1983), the biotype 3, isolated from samples collected from all over the island was pathogenic to all solanaceous crops. He further stated that the wet and dry climatic zones haven't apparently had any effect on the distribution of the biotypes of $R$. solanacearum. In addition, Bandara, (1983) reported that many samples of $P$. solanacearum collected from the hill country dry zone were found to carry Pseudomonas marginalis which had a synergistic effect on the wilt disease occurrence. P. marginalis showed similar biochemical reactions as the biotype 4 of $P$. solanacearum. This is a crucial finding in regard of wilt infections in Sri Lanka.

\section{Management of tomato bacterial wilt}

It was reported that the economic loss of tomato due to bacterial wilt is greater than any other crop (Hayward, 1995). Therefore, control of this disease is an essential prerequisite for a high profit targeted tomato cultivation. The causal agent of bacterial wilt, $R$. solanacearum, is a complex, heterogeneous species. Disease control has become difficult due to its wide host range, wide spread and vast genetic diversity of the pathogen (Hayward, 1991). Various control strategies including the induction of host resistance (Dalal et al., 1999; Hase et al., 2008), development of transgenic resistant varieties (Jia et al., 1999), adhering to appropriate cropping systems (Dalal et al., 1999), soil amendments (Vincent \& Mew, 1998) and the practice of integrated control (Katayama \& Kimura, 1987) and biological control (Guo et al., 2003) have been adopted in many cases (Table 1). Table 1 indicates control strategies employed for the management of bacterial wilt of tomato. Among them breeding for disease resistance has been a promising approach (Persely, 1986).

Wang et al., (1998), evaluated thirty five tomato lines to form an international set of resistance sources to bacterial wilt infection. 
Table1. Control strategies used for the management of bacterial wilt of tomato

\begin{tabular}{|c|c|c|}
\hline Control measure & Tomato variety & Reference \\
\hline $\begin{array}{l}\text { Induction of disease resistance in tomato through } \\
\text { Jasmonic acid signaling by Pythium oligandrum. }\end{array}$ & $\begin{array}{l}\text { Moneymaker and Micro- } \\
\text { Tom }\end{array}$ & Hase et al., 2008 \\
\hline $\begin{array}{l}\text { Selection of bacterial wilt resistant tomato through } \\
\text { tissue culture }\end{array}$ & $\begin{array}{l}\text { Lycopersicon esculentum } \\
\text { (Mill cv. Fuknju No.2) }\end{array}$ & Toyoda et al., 1989 \\
\hline Evaluation of oligogenic resistance to tomato wilt. & $\begin{array}{l}71 \mathrm{~F} 2 \text { individuals of a cross } \\
\text { between a resistant and a } \\
\text { susceptible parent against } \\
\text { bacterial wilt }\end{array}$ & Danesh et al., 1994 \\
\hline Integrated management & $\begin{array}{l}\text { Solar set (race } 1 \text { biovar } 1 \text { )- } \\
\text { susceptible variety }\end{array}$ & Anith et al., 2004 \\
\hline Application of the biofumigant, Thymol & Equinox cultivar & Ji et al., 2005 \\
\hline $\begin{array}{l}\text { Avirulent mutants of Pseudomonas solanacearum } \\
\text { for the biological control }\end{array}$ & Susceptible H63-5 & $\begin{array}{l}\text { Trigalet \& Trigalet- } \\
\text { Demery, } 1990\end{array}$ \\
\hline $\begin{array}{l}\text { Biological control using soil borne antagonists - } \\
\text { Bacillus megaterium, Enterobacter cloacae, } \\
\text { Pseudomonas guillermondii, Candida ethanolica. }\end{array}$ & & $\begin{array}{l}\text { Nguyen \& } \\
\text { Ranamukhaarachchi, } \\
2010\end{array}$ \\
\hline Usage of clove oil & & $\begin{array}{l}\text { Huang \& Lakshman, } \\
2010\end{array}$ \\
\hline
\end{tabular}

Bacterial wilt resistant commercial varieties, breeding lines and wild tomato accessions were used in this study. Danesh et al., (1994), evaluated oligogenic resistance to tomato wilt through a cross between a resistant and a susceptible parent. The selection of bacterial wilt resistant tomato has also been attempted by Toyoda et al., (1989) through tissue culture techniques using the Fuknju No.2 tomato Mill variety. There are several bacterial wilt resistant tomato varieties viz. KWR, T245, T146, Bathiya, Maheshi, Thilina, Rajitha, Rashmi which are developed and released by the Department of Agriculture, Sri Lanka.
In addition, Abeygunawardana \& Siriwardana (1963) pointed out that Thalatuoya and Rahangala selection II have greater resistance to wilt while Senarathne et al., (2012) revealed that local varieties such as Bathiya, Maheshi, Thilina, Rajitha are resistant to bacterial wilt. Senarathna et al., (2012) also publicized nine exotic tomato varieties (G.W.G. 502, G.W.G. 305, Rohit 2, Hero, Maganda, 08T 420, 08T 906, 08T 917, Monaco-NP-12) which are resistant to wilt infection. However, the high diversity of the pathogen and the location specific nature of resistance have caused certain problems in the production of resistant 
cultivars against tomato bacterial wilt (Acosta et al., 1995).

According to the studies by Senarathne et al., (2012), of the 16 exotic varieties, BSS 908, Rashmi 8005, Balady, BigStrike, Rijuta, Maganda, Rajshri (recently introduced by private seed companies), 08T 420, 08T 917, Rohit-2, Monaco NP12, Malan and Hero (exotic varieties) are susceptible to bacterial wilt or blight disease in the mid country wet zone of Sri Lanka. The research team recommends GWG 305, GWG 502 and 08T 906 varieties for cultivation in mid country wet zone areas of Sri Lanka.

According to Oda, (1995), Lee, (1994) and Ilankoon, (2001), grafting of tomato varieties to disease resistant stocks has been successfully used as an effective control measure. The team specifically studied grafting as a successful remedy for the bacterial wilt disease. As revealed in a survey done in Japan in 1995, 45$66 \%$ of tomato cultivated in protected agricultural systems was grafted tomato plants (Oda, 1995). Ilankoon, (2001), reports that of the two locally recommended wilt resistant varieties, KWR is a better root stock than T 245 for obtaining wilt resistant seedlings of the Daniella hybrid, while both rootstocks can be used for the SS 100 hybrid in Sri Lanka.

Integrated tomato wilt management has been also attempted as a control measure for the wilt disease. Once Anith et al., (2004) managed the bacterial wilt infection of a susceptible variety Solar set (Race 1, Biovar 1) using different combinations of plant growth promoting rhizobacteria, Pseudomonas putida, Bio Yield (two Bacillus strains), Equity (40 different microbial strains), Actigard and $\mathrm{S}-\mathrm{H}$ mixture. Accordingly integrated management of bacterial wilt in tomato is successful in various ways. Different combinations have resulted in the successful management of tomato wilt.

Induction of host systemic resistance is also a successful approach in disease management. Hase et al., (2008) have studied the ability of Pythium oligandrum in inducing tomato plant's systemic resistance (Money maker and Micro-Tom varieties) through Jasmonic acid signaling against the bacterial wilt pathogen $R$. solanacearum.

Biological control of the bacterial wilt pathogen, $R$. solanacearum has also been attempted by many scientists. Vesiculararbuscular mycorrhizae (Halos \& Zorilla, 1979), avirulent mutants of $R$. solanacearum (Dong et al., 1999), genetically engineered antagonistic bacteria (Kang et al., 1995) and some naturally occurring antagonistic rhizobacteria such as Bacillus spp. (Silveira, 1995), Pseudomonas spp. (Guo et al., 2001) and Streptomyces spp. (Albyad et al., 1996), plant growth promoting rhizobacteria (PGPR) (Guo et al., 2004) have been successfully used as biological control agents against $R$. solanacearum. Once Ji et al., (2004) successfully managed $R$. solanacearum through the application of the biofumigant Thymol to equinox cultivar. Nguyen \& Ranamukhaarachchi, (2010) used Bacillus megaterium, Enterobacter cloacae, Pseudomonas guillermondii, Candida ethanolica, the soil borne antagonists to control the bacterial wilt causal agent. Using the susceptible tomato cultivar H63-5, Trigalet \& Trigalet-Demery, (1990) tested the biological control ability of Tn-5 induced avirulent mutants of Pseudomonas solanacearum against $R$. solanacearum. 
In addition to these, the usage of soil less, single solid media has also been practiced as a remedy for this soil borne bacterial infection. Although much work has not been done on this strategy, it seems a strategy that could be applied widely. As reported previously, of these different control measures, biological control of $R$. solanacearum and usage of wilt resistant tomato cultivars have been the most promising.

Wilt caused by the fungus Fusarium oxysporum is also a common infection in tomato in many parts of the world in addition to the wilt infection caused by Verticillium albo-atrum.

\section{Fusarium wilt in tomato}

Fusarium wilt is another highly destructive disease found in commercial tomato cultivations grown under either green house or field conditions in many warm regions of the world. It is caused by a soil borne pathogen, Fusarium oxysporum f.sp. lycopersici. This infection is reported to cause $10-50 \%$ yield loss in tomato (Larkin \& Fravel, 1998; Borerro et al., 2004).

The plants infected with Fusarium oxysporum suddenly show signs of wilting. Lower leaves turn yellow and start to die. Finally the whole plant wilts and dies within few days. The soil borne pathogen colonizes the vascular system of the plant, destroys the xylem vessels which transport water and nutrients and thereby causing the plant to wilt. These symptoms are somewhat similar to bacterial wilt symptoms.

\section{Management of tomato Fusarium wilt}

The proper management of the causal agent of fusarium wilt, the soil borne Fusarium oxysporum has not been successful as the fungus lives particularly in or near the dynamic environment of the rhizosphere and can frequently survive long periods in soil with the help of resistant structures. It has been recorded that the commonly applied control measures against this pathogen infection are pre plant fumigation and fungicide application (Larkin \& Fravel, 1998). In addition, biological control (Srivastava et al., 2010; Haruna et al., 2012) and induction of host resistance (De Cal et al., 1997; Fuchs et al., 1997; Samia \& Khalal, 2007) have also been tested and successfully used in controlling Fusarium wilt (Table 2).

Several different methods have been attempted to manage the Fusarium wilt disease. Induction of host resistance and biological control has been prominent among other approaches. The defense mechanisms of a tomato plant have been activated through the induction of the expression of $\beta$-fructosidase (Benhamou et al., 1991) by a combination of chitosan and endophytic bacterial strain (Benhamou et al., 1998), the application of Pseudomonas fluorescens and a nonpathogenic $F$. oxysporum (Duijff et al., 1998) and by applying three types of composts against the causal agent $F$. oxysporum (Fattah \& Al-Amri, 2012).

It was reported that, various fungal and bacterial bio-control organisms (Nonpathogenic Fusarium spp., Trichoderma spp., Gliocladium virens, Pseudomonas fluorescens, Burkholderia cepacia, F. oxysporum, F. solani, combinations of multiple Fusarium 
Table 2. Control strategies used for managing Fusarium wilt of tomato

\begin{tabular}{|c|c|c|}
\hline Control measure & Tomato variety & Reference \\
\hline $\begin{array}{l}\text { Application of systemic fungicides (prochloraz, } \\
\text { carbendazim, thiram, toclofos-methyl, hymexazol, } \\
\text { azoxystrobin and carboxin) using a deep flow } \\
\text { technique (hydroponic system). }\end{array}$ & $\begin{array}{l}\text { Lycopersicon esculentum } \\
\text { (Mill) against fusarium wilt }\end{array}$ & Song et al., 2004 \\
\hline $\begin{array}{l}\text { Biological control using nonpathogenic Fusarium spp., } \\
\text { Trichoderma spp., Gliocladium virens, Pseudomonas } \\
\text { fluorescens, Burkholderia cepacia, F. oxysporum, F. } \\
\text { solani, combinations of multiple Fusarium isolates, } \\
\text { Fusarium with bacteria and Fusarium with other fungi. }\end{array}$ & $\begin{array}{l}\text { Bonny Best cultivar against } \\
\text { fusarium wilt }\end{array}$ & Larkin \& Fravel, 1998 \\
\hline $\begin{array}{l}\text { Biological control using non pathogenic Fusarium spp. } \\
\text { (CS-1, CS-20 \& FO 47) }\end{array}$ & $\begin{array}{l}\text { Bonny Best cultivar against } \\
\text { fusarium wilt }\end{array}$ & Larkin \& Fravel, 1999 \\
\hline Application of composts as resistance inducers. & & $\begin{array}{l}\text { Abdel Fattah \& Al- } \\
\text { Amri, } 2012\end{array}$ \\
\hline Suppression by endophytic bacteria. & $\begin{array}{l}\text { Dansk Export against } \\
\text { Fusarium oxysporum and } \\
\text { Verticillium dahliae }\end{array}$ & $\begin{array}{l}\text { Nejad \& Johnson, } \\
2000\end{array}$ \\
\hline $\begin{array}{l}\text { Biological control of Fusarium oxysporum, fusarium } \\
\text { wilt causing fungus, using fluorescent Pseudomonas, } \\
\text { Trichoderma harzianum and Glomus intraradices an } \\
\text { arbuscular myccorhizal fungus alnoe and as } \\
\text { combinations. }\end{array}$ & & Srivastava et al., 2010 \\
\hline $\begin{array}{l}\text { Biological control through detoxification of fusaric acid } \\
\text { by a fusaric acid resistant mutant of Pseudomonas } \\
\text { solanacearum. }\end{array}$ & Zuiko and Ponderosa & Toyoda et al., 1988 \\
\hline Usage of vermicompost. & Remiz F1 & Szczech, 1999 \\
\hline $\begin{array}{l}\text { Induction of disease resistance by a combination of } \\
\text { chitosan and endophytic bacterial strain. }\end{array}$ & $\begin{array}{l}\text { Bonny Best against } \\
\text { Fusarium wilt }\end{array}$ & Benhamou et al., 1998 \\
\hline Induction of the expression of $\beta$-fructosidase. & $\begin{array}{l}\text { Susceptible and resistant } \\
\text { tomato (Lycopersicon } \\
\text { esculentum) against } \\
\text { fusarium wilt }\end{array}$ & Benhamou et al., 1991 \\
\hline $\begin{array}{l}\text { Induction of systemic resistance by Pseudomonas } \\
\text { fluorescens and by non pathogenic F. oxysporum. }\end{array}$ & $\begin{array}{l}\text { Monalbo cultivar } \\
\text { susceptible to all races of } \\
\text { Fusarium oxysporum f.sp. } \\
\text { lycopersici. }\end{array}$ & Duijff et al., 1998 \\
\hline
\end{tabular}


isolates, Fusarium with bacteria and Fusarium with other fungi) have been applied to control the Fusarium wilt in tomato (Larkin \& Fravel, 1998). Larkin \& Fravel, (1999) have also tried nonpathogenic Fusarium spp. (CS-1, CS20 \& FO 47) for their biocontrol ability against $F$. oxysporum while Nejad and Johnson, (2000) studied the suppression of the tomato wilt disease by endophytic bacteria isolated from roots and stems. Srivastava et al., (2010) also studied the biological control potential of fluorescent Pseudomonas, Trichoderma harzianum and Glomus intraradices an arbuscular myccorhizal fungus alone and as combinations. A fusaric acid resistant mutant of Pseudomonas solanacearum also has been successful in controlling the Fusarium wilt causal agent (Toyoda et al., 1988). Szczech, (1999), studied the potential of vermicompost in suppressing F. oxysporum.

\section{Verticillium wilt in tomato}

Tomato wilt is also caused by infection of soil borne pathogenic fungus Verticillium albo-atrum. This pathogenic fungus attacks the roots, travels up along the xylem vessels and blocks them. This hinders the normal flow of water and nutrients to the leaves. Older leaves become yellow or brown and stems tend to discolour. Eventually the plant dies. This infection is much favoured under cold weather and difficult to manage due to the ability of this fungus to persist in soil for a longer period. Crop rotation, well maintained field conditions and usage of resistant varieties have been successfully applied as control measures of this infection.
In addition, southern blight and walnut wilt diseases too cause wilting symptoms in tomato. But these infections are not prominent in causing economic losses in tomato. Therefore paying attention on minimizing these minor infections also would lead to healthy tomato cultivation and thereby gain a higher profit.

Tomato wilt diseases recorded in Sri Lanka

In Sri Lanka, tomato wilt is primarily caused by the bacterium $R$. solanacearum. Other types of wilt infections such as Verticillium wilt or southern blight infection of tomato are not reported from Sri Lanka. Detection of the incidence and possibility in infection of these two wilt threats is also worthwhile to ensure wilt free tomato cultivations. Although biological control and usage of resistant cultivars have been the most effective and widely studied control measures worldwide, biological control of bacterial wilt has not been applied in managing the bacterial wilt threat in Sri Lanka though some attempts have been made. However, the evaluation of resistant cultivars has been conducted to a satisfactory level. Induction of tomato host resistance is also a successful strategy studied by many scientists in managing tomato wilt. Unfortunately the use of this strategy has not been investigated in Sri Lanka. Identification of the biological approaches (biological control and host defense induction) in managing this significant infection would be also worthwhile with regard to sustainable agriculture. 


\section{Wilt infections in Chilli}

Wilt is reported to be the most frequently encountered disease problem in chilli (Skaggs et al., 2000; Siddiqui \& Akhtar, 2007). Wilting of chilli could be due to infections brought by bacteria, fungi, virus or nematodes. Fusarium wilt, bacterial wilt, phytopthora root rot, pythium root rot, verticillium wilt and rhizoctonia root rot are several different types of wilt diseases detected in chilli (Sanogo, 2003). Young chilli plants at a vegetative stage are more susceptible to wilting and infected plants show withering off of leaves, a dark streak developing upward from the collar region and ultimately plants die due to death of the xylem tissues (Figure 2). In Southern New Mexico, 43\% of the chili producers have reported wilt as the most frequently encountered disease problem in chilli (Skaggs et al., 2000). The annual income loss due to these wilt infections is reported to be between $20-25 \%$ in Sri Lanka (Kelaniyangoda, 2011).

\section{Fusarium wilt in chilli}

It was reported that Fusarium oxysporum is the main causal organism for wilt in chilli. Wilt disease caused due to this fungal infection is common in chilli worldwide compared to the other wilt infections.

The pathogen infects young roots, grows, develops and spreads in root and stem vascular vessels inhibiting water and nutrient transportation (Miller et al., 1986). Therefore, the leaves of chilli plants first tend to wither and thereafter lead to the death of the whole plant. The characteristic symptoms of the disease are brown vascular discoloration followed by upward and inward rolling of the upper leaves and subsequently wilting of the plant (MacHardy \& Beckman, 1981; Rivelli, 1989). The chilli yield loss due to this Fusarium wilt disease reportedly varies between 10 80\% worldwide (Loganathan et al., 2013).

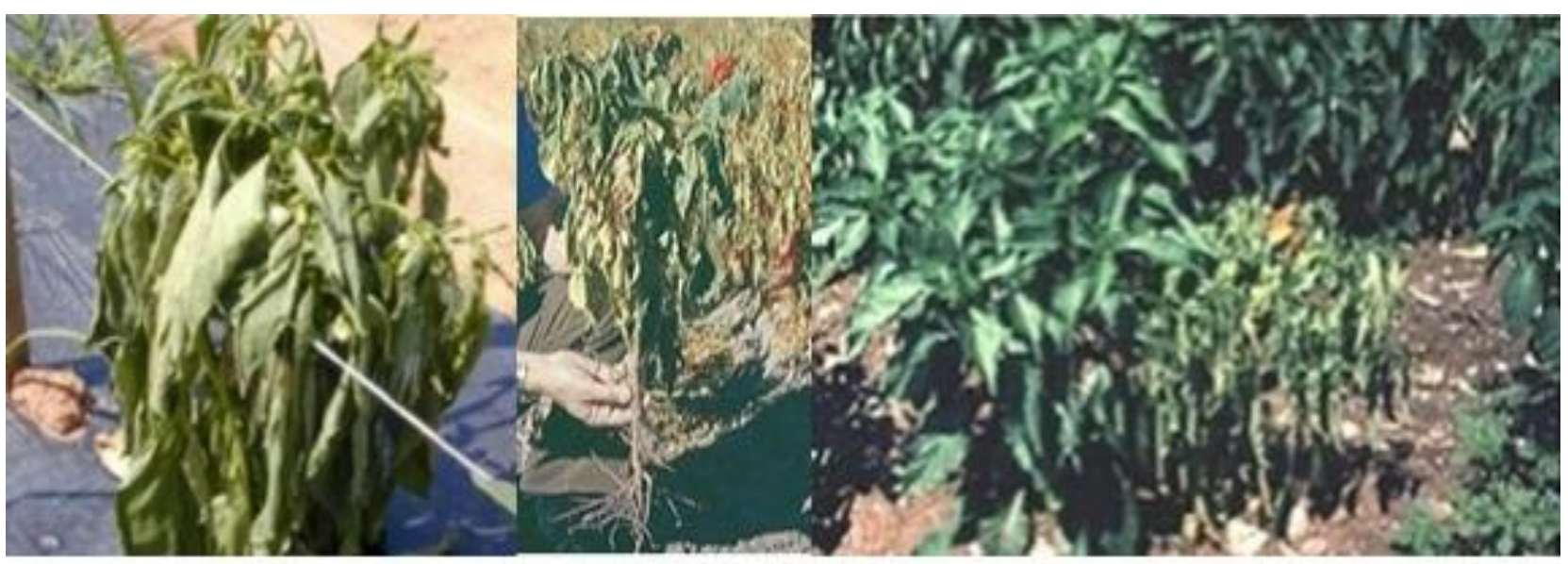

Figure 2. Wilt symptoms of chilli (source: D. Lindsey) 
Several species of soil borne Fusarium are responsible for the wilt disease of chilli. $F$. oxysporum, F. solani, F. moniliforme and $F$. pallidoroseum have been reported as wilt causing agents of chilli. F. oxysporum and $F$. solani are the most prevalent species of Fusarium found associated with wilt of chilli in India (Naik, 2006).

\section{Management of chilli Fusarium wilt}

Several biological control approaches (usage of antagonistic microorganisms, botanicals, dairy components, essential oils, resistance inducers) and integrated management is one of the main strategies that has been adopted to manage the fusarium wilt in chilli (Table 3). Different antagonistic microorganisms such as chitinolytic bacteria (Suryanto et al., 2010), Trichoderma harzianum, T. viridae, T. aureiviride, Bacillus subtilis and Pseudomonas fluorescens (Ragab et al., 2012), T. koningii and T. aureoviridae (Sahi \& Khalid, 2007) have been successfully applied in controlling the Fusarium spp. infection in chilli. Singh et al., (2017) evaluated twelve botanicals for their inhibitory activity against $F$. oxysporum inciting wilt disease in chilli while Shafique et al., (2015) and Suprapta \& Khalimi, (2012) evaluated the antifungal effect of methanolic leaf extracts of Eucalyptus citriodora and 14 selected tropical plants in Bali island. Essential oils (Cinnamon, clove, thyme, lemon grass, lemon, mint, pepper mint, mustard) in suppressing fungal growth and chemical plant resistance inducers such as sodium benzoate, potassium bicarbonate, potassium sorbate and chitosan in induction of resistance against the wilt causal agent $F$. oxysporum were tested by Ragab et al., (2012). The

Sri Lankan Journal of Biology 3(2) possibility in usage of cow and buffalo dairy components in managing $F$. oxysporum infection has also been attempted by Maharaja et al., (2017).

\section{Bacterial wilt in chilli}

Bacterial wilt in chilli is also caused by the same pathogenic bacterium Ralstonia solanacearum as in the tomato bacterial wilt (Hayward, 1994). Due to this infection, chilli leaves wither off as the initial symptom and subsequently, the entire plant wilts with no yellowing of leaves while brown colour lesions appear in the root area. According to a study done in Brazil, bacterial wilt infection of Capsicum was due to Ralstonia solanacearum (biovar III). Field observations have further indicated that biovar III isolates have been apparently more virulent and aggressive for Capsicum species by inciting severe wilt and vascular discolouration while biovar I induces less severe symptoms and dwarfism and partial wilting even under disease favourable conditions (Takatsu \& Lopes, 1997; Coelho Neto et al., 2003).

Several control strategies have been tried out in managing the bacterial wilt infection in Capsicum annuum worldwide (Table 4).

Cultivation of resistant chilli varieties is one of the promising approaches in effective control of this highly variable bacterial infection in solanaceous crops (Peter et al., 1993; Hartman \& Elphinstone, 1994; Wang et al., 2000). Wang \& Berke (1997), have evaluated the bacterial wilt resistance in 17 Capsicum annuum accessions maintained in the Asian Vegetable Research and Development Centre (AVRDC) by 
Table 3. Control strategies used for the management of fusarium wilt of chilli

\begin{tabular}{lll}
\hline Control strategy & Chilli & Reference \\
variety/cultivar & \\
\hline
\end{tabular}

Application of chitinolytic bacteria.

Usage of cow and buffalo dairy components.

Use of botanicals.

Antagonistic bioagents (Trichoderma

harzianum, T. viridae, T. aureiviride, Bacillus

subtilis and Pseudomonas fluorescens), essential oils (Cinnamon, clove, thyme, lemon grass, lemon, mint, pepper mint, mustard) and chemical pant resistance inducers (Sodium benzoate, Potassium bicarbonate, Potassium sorbate and chitosan).

Antifungal effect of methanolic leaf extracts of Eucalyptus citriodora.

In vitro biocontrol activity of Trichodrma viride, T. harzianum, T. koningii, $T$. aureoviridae against $F$. oxysporum.

Methanolic extracts of 14 selected tropical plants.

Application of individual and combined forms of microbial antagonists (Trichoderma viridae, T. harzianum, P. fluorescens and Bacillus sp.). Integrated control approach for wilting of chilli plants in green houses
PT. Tanindo Subur

Prima, Surabaya

Maharaja et al., 2017

Singh et al., 2017

Ragab et al., 2012

Golden hot, Revival, Shafique et al., 2015 Hot chili, Saim hot, Sky red, P6, Neelam, Sitara, Anchal and Kundri

Sahi \& Khalid, 2007

Suprapta \& Khalimi, 2012

Kashmir Long-1

Dar et al., 2015

Kelaniyangoda et al., 2011 
inoculating the plants with biovar III, $R$. solanacearum isolate. A 39\% of the tested genotypes were affected with wilt symptoms. In Brazil, Matos et al., (1990), screened 45 Capsicum accessions detecting high resistance levels in three lines viz. 'MC-4' ('CNPH-143'), 'MC-5' ('CNPH-144') and 'HC-10' ('CNPH-145'). Lopes and Boiteux (2004), studied and evaluated the reaction of Capsicum accessions (23 previously selected as bacterial wilt resistant and two susceptible controls) to $R$. solanacearum biovar I or III isolates.

Application of microbial bioagents with a biocontrol potential against $R$. solanacearum is also a strategy which has been frequently applied in recent times (Bora et al., 2015). There they employed five different saprophytic antagonists (Trichoderma parareesei TPJ-S-1, Trichoderma viride TVJ-S-1, Paecilomyces variotti, Bacillus thuringiensis BTJ-S-1 and Critobacter farmer CTJ-S-1 and their consortial formulations) against $R$. solanacearum.

The main control measures taken against the Fusarium wilt infection of chilli worldwide are biological green approaches such as the application of biological control agents: antagonistic microorganisms, botanicals, induction of host systemic resistance etc. However, only one study was carried out on chilli wilt in Sri Lanka (Kelaniyangoda, 2011). As reported, the chilli wilt detected in Sri Lanka is caused as a result of a series of fungal infections and not due to a bacterial infection. Chemical treatments have been tested and were successful in reducing chilli wilt in Sri Lanka caused by Fusarium sp. (Kelaniyangoda et al., 2011). It had been mentioned that a controlled irrigation supplement was also important in the management of the disease. In comparison to efforts elsewhere in using biological control measures for the management of the disease, no such strategies have been studied in Sri Lanka.

\section{Other wilt infections in chilli}

Wilt in chilli could also result from infections of Phytophthora spp., Pythium spp., Rhizoctonia solani and Verticillium dahlia. Phytophthora root rot is caused by the fungus-like organism Phytophthora capsici. Infection of the root and lower portions of the stem leads to plant wilting. Gradually wilting is displayed over the entire field. Phytophthora capsici produces zoospores, which enable the spread of the pathogen from plant to plant. Management of $P$. capsici involves reducing soil water saturation, using resistant cultivars if available, reducing populations of the pathogen through crop rotation, soil solarization, application of organic amendments, restricting pathogen dispersal through mulching and the judicious use of fungicides such as metalaxyl or mefenoxam (Ristaino \& Johnston, 1999).

Verticillium wilt of chilli is caused by Verticillium dahliae and $V$. albo-atrum. Visual symptoms of the disease include stunting, defoliation, and wilting, with discoloration of the vascular system. In the field, the disease first appears in a single plant or a small group of wilting plants scattered throughout the field, depending on the distribution of the pathogen in the soil. The disease gradually spreads and may cover the entire field. Infected plants may exhibit physiological changes such as the reduction in photosynthesis, increased plant transpiration, and respiration. 
Table 4. Control strategies used for the management of bacerial wilt of chilli

\begin{tabular}{lll}
\hline Control strategy & Chilli variety/cultivar & Reference \\
\hline $\begin{array}{l}\text { Application of five different saprophytic } \\
\text { antagonists (T. parareesei TPJ-S-1, }\end{array}$ & $\begin{array}{l}\text { Naga chilli (Capsicum } \\
\text { chinese Jacq.) }\end{array}$ & Bora et al., 2015 \\
$\begin{array}{l}\text { Trichoderma viride TVJ-S-1, Paecilomyces } \\
\text { variotti, Bacillus thuringiensis BTJ-S-1 and }\end{array}$ & & \\
$\begin{array}{l}\text { Critobacter farmer CTJ-S-1 and their } \\
\text { consortial formulations in effective } \\
\text { management of bacterial wilt disease in } \\
\text { chilli. }\end{array}$ & \\
$\begin{array}{l}\text { Inbred lines MC-4, PBC-631, PBC 066, PBC } \\
\text { 1347, PBC 473 are suitable for breeding } \\
\text { programs to develop pungent and/or sweet } \\
\text { cultivars with a stable, broad spectrum } \\
\text { resistance to bacterial wilt pathogen, } R .\end{array}$ & Lopes \& Boiteux, 2004 \\
solanacearum. & \\
\end{tabular}

Although a tremendous effort has been made to identify resistance to Verticillium wilt, it has still not been successful, as currently there are no commercially acceptable cultivars that are genetically resistant to this disease. Application of chloropicrin and metamsodium fumigants and the use of organic amendments, may decrease Verticillium wilt through reduction of pathogen populations in the soil (Lazarovits et al., 2000).

According to Kelaniyangoda et al., (2011), species of Fusarium, Pythium and Phytophthora are responsible for the chilli wilt disease in Sri Lanka. As they further report chilli plants initially get infected by oomycetes such as Pythium and Phytophthora and subsequently become susceptible to infections of Fusarium sp. This primary infection of Pythium and Phytophthora spp. does not result in any visible symptoms.
However, the secondary infection of Fusarium spp. is visible and results in wilting of the chilli plants. Studies on this infection in Sri Lanka are lacking but is much needed to make the cultivation of chillies more profitable.

This review clearly emphasizes the validity to carry out more detailed studies on tomato and chilli wilt infections in Sri Lanka and to formulate more effective control strategies to meet the increasing demand for these crops.

\section{Conclusion}

Wilt diseases of tomato and chilli are common, economically important infection in both crops worldwide. It was reported that tomato wilt is caused mainly by bacterial ( $R$. solanacearum) and fungal (Fusarium spp.) infections while 
chilli wilt is mainly due to fungal (Fusarium spp.) infection. Worldwide tomato wilt is controlled through many strategies such as the usage of resistant cultivars, biological control, host defense induction and integrated management while chilli wilt management focuses mainly on biological and chemical approaches.

\section{References}

Abeygunawardena, D.V.W., Siriwardena, A. A. P. (1961) Disease hazards in potato cultivation. II. Brown rot or bacterial wilt caused by Pseudomonas solanacearum, Tropical Agriculturist 117: 221-225.

Abeygunawardena, D.V.W., Siriwardena, A. A. P. (1963) Studies on resistance in tomato to bacterial wilt, Tropical Agriculturist 119: 5566.

Acosta, J.C., Gilbert, J.C., Quonon, V.L. (1995) Heritability of bacterial wilt resistance in tomato, Proceedings of the American Society of Horticultural Science 25: 84-85.

el Albyad, M.S., el Sayed, M.A., el Shanshoury, A.R. (1996) Effect of culture conditions on the antimicrobial activities of UV- mutants of Streptomyces corchorussi and $S$. spiroverticillatus against bean and banana wilt pathogens, Microbial Resources 151: 201211.

Anith, K.N., Momol, M.T., Kloepper, J.W., Marois, J.J., Olson, S.M., Jones, J.B. (2004) Efficacy of plant growth promoting rhizobacteria, acibenzolar-S-Methyl and soil amendment for integrated management of bacterial wilt on tomato, Plant Diseases 88: 669-673.

Bandara, J.M.R.S. (1983) Biotype distribution of vascular wilt pathogen Pseudomonas solanacearum in Sri Lanka, Journal of National Science Council, Sri Lanka 11(1): 65-76.
Bandara, J.M.R.S. (1984) Effect of chemical treatments and incorporation of organic matter on the pathogenicity and survival of Pseudomonas solanacearum (Smith) in soil, Journal of National Science Council, Sri Lanka 12(2): 223-233.

Benhamou, N., Kloepper, J.W., Tuzun, S. (1998) Induction of resistance against Fusarium wilt of tomato by combination of chitosan with an endophytic bacterial strain: ultrastructure and cytochemistry of the host response, Planta 204: 153-168.

Benhamou, N., Grenier, J., Chrispeels, M.J. (1991) Accumulation of $\beta$-fructosidase in the cell walls of tomato roots following infection by a fungal wilt pathogen, Plant Physiology 97: 739-750.

Bora, L.C., Kataki, L., Talukdar, K., Nath, B.C., Sarkar, R. (2015) Molecular characterization of microbial antagonists and development of bioformulations for management of bacterial wilt of NAGA chilli (Capsicum chinens Jacq.) in Assam. Journal of Experimental Biology and Agricultural Sciences 3(2): 109-122.

Borrero, C., Trillas, M.I., Ordovas, J., Tello, J.C., Aviles, M. (2004) Predictive factors for the suppression of fusarium wilt of tomato in plant growth media, Phytopathology 94(10): 1094-1101.

Champoiseau, P.G., Momol, T.M. (2009) Bacterial wilt of tomato, The United States Department of Agriculture- National Research Initiative programme, 1-11p.

Coelho Netto, R.A., Noda, H., Boher, B. (2003) Aggressiveness of Ralstonia solanacearum isolates from solanaceae in the state of Amazons, Summa Phytopathogica 29: 208211.

Danesh, D., Aarons, S., McGill, G.E., Young, N.D. (1994) Genetic dissection of oligogenic resistance to bacterial wilt in tomato, Molecular Plant Microbe Interactions 7(4): 464-471. 
Dalal, N.R., Dalal, S.R., Golliwar, V.G., Khobragade, R.I. (1999) Studies on grading and pre-packaging of some bacterial wilt resistant brinjal (Solanum melongena L.) varieties, Journal of Soils Crops 9: 223-226.

Dar, G.H., Mir, G.H., Rashid, H., Dar, W.A., Majeed, M. (2015) Evaluation of microbial antagonists for the management of wilt/root rot and damping off diseases in chilli (Capsicum annum), VEGETOS 28(4): 102-110.

De Cal, A., Pascual, S., Melgarejo, P. (1997) Involvement of resistance induction by Penicillium oxalicum in the biocontrol of tomato wilt, Plant Pathology 46(1): 72-79.

Dong, C., Zeng, X., Liu, Q. (1999) Biological control of tomato bacterial wilt with avirulent bacteriocinogenic strain of Ralstonia solanacearum. Journal of South China Agriculture University 20: 1-4.

Duijff, B.J., Pouhair, D., Olivain, C., Alabouvette, C., Lemanceau, P. (1998) Implication of systemic induced resistance in the suppression of Fusarium wilt of tomato by Pseudomonas fluorescens WCS417r and by nonpathogenic Fusarium oxysporum Fo47. European Journal of Plant Pathology 104: 903-910.

Fattah, A.G.M., Al-Amir, S.M. (2012) Induced systemic resistance in tomato plants against Fusarium oxysporum f.sp. lycopersici by different kinds of compost, African Journal of Biotechnology 11(61): 12454-12463.

Fuchs, J.G., Moenne-Loccoz, Y., Defago, G. (1997) Non-pathogenic Fusarium oxysporum strain Fo47 induces resistance to fusarium wilt in tomato, Plant Disease 81(5): 492-496.

Galanihe, L.D., Priyantha, M.G.D.L., Yapa, D.R., Bandara, H.M.S., Ranasinghe, J.A.D.A.R. (2004) Annals of the Sri Lankan Department of Agriculture 6: 99-106.

Gunathilake, P.M.P.C.K., Bandara, J.M.R.S., Samarajeewa, P.K. (2004) Genetic diversity and pathogenicity of Ralstonia solanacearum E.F.Smith in tomato (Lycopersicon esculentum Mill) in Kandy, Matale and Monaragala districts, Tropical Agricultural Research 16: 51-60.

Gunawardena, Jinaderie, Udugama, Srimathie, Senevirathne, S.N. De S. (1980) New hosts of Pseudomonas solanacearum, Proceedings of the thirty sixth annual sessions of the Sri Lanka association for the Advancement of Science, $\mathrm{p}$ 34.

Guo, J.H., Qi, H.Y., Guo, Y.H., Ge, H.L., Gong, L.Y., Zhang, L.X., Sun, P.H. (2004) Biocontrol of tomato wilt by plant growth promoting rhizobacteria, Biological Control 29: 66-72.

Guo, J.H., Guo, Y.H., Zhang, L.X., Qi, H.Y., Fang, Z.D. (2001) Screening for biocontrol agents against cayenne pepper bacterial wilt, Chinese Journal of Biological Control 17: 101-106.

Halos, P.M., Zorilla, R.A. (1979) Vesicular arbuscular mycorrhizae increase growth and yield of tomatoes and reduce infection by Pseudomonas solanacearum, Phil Agri. 62: 309- 315.

Hartman, G.L., Elphinstone, J.G. (1994) Advances in the control of Pseudomonas solanacearum race 1 in major food crops. In: Hayward, A.C. and Hartman, G.L. (eds), Bacterial wilt: the disease and its causative agent, Pseudomonas solanacearum. pp. 157177, CAB International, Wallingford.

Hase, S., Takahashi, S., Takenaka, S.,Nakaho, K., Arie, T., Seo, S., Ohashi, Y., Takahashi, H. (2008) Involvement of jasmonic acid signalling in bacterial wilt disease resistance induced by biocontrol agent Pythium oligandrum in tomato, Plant pathology 57(5): 870-876.

Hayward, A.C. (1964) Characteristics of Pseudomonas solanacearum, Journal of Applied Bacteriology 27: 265-277.

Hayward, A.C. (1991) Biology and epidemiology of bacterial wilt caused by Pseudomonas solanacearum, Annual Review of Phytopathology 29: 65-87.

Hayward, A.C. (1995) Pseudomonas solanacearum. In: Singh, U.S., Singh, R.P., Kohmoto, K. (eds), Pathogenesis and host 
specificity in Plant Disease: Histopathological, biochemical, genetic and molecular bases, Elsivier, Tarrytown 1: 139-151.

Hayward, A.C. (1994) The hosts of Pseudomonas solanacearum In: Hayward, A.C. and Hartman, G.L. (eds), Bacterial Wilt: The Disease and Its Causative Agent, Pseudomonas solanacearum, CAB International. pp. 9-24, Wallingford.

Huang, Q., Lakshman, D.K. (2010) Effect of clove oil on plant pathogenic bacteria and bacterial wilt of tomato and geranium, Journal of Plant Pathology 92(3): 701-707.

Ilankoon, J., Zoysa, I.J.D., Wijesekara, A. (2001) Tomato grafting as a remedy for bacterial wilt in a protected agriculture system, Annals of the Sri Lankan Department of Agriculture 3: 53-60.

Jabeen, N., Ahmed, N., Ghani, M.Y., Sofi, P.A. (2009) Role of phenolic compounds in resistance to chilli wilt, Communications in Biometry and Crop Science 4(2): 52-61.

Ji, P., Momol, M.T., Olson, S.M., Pradhanang, P.M., Jones, J.B. (2005) Evaluation of thymol as biofumigant for control of bacterial wilt of tomato under field conditions, Plant Disease 89: 497-500.

Jia, S., Qu, X., Feng, L., Tang, T., Tang, Y., Liu, K., Zheng, P., Zhao, Y., Bai, Y., Cai, M. (1999) Expression of antibacterial peptide gene in transgenic potato confers resistance to bacterial wilt, Chinese Agricultural Sciences, Biejing, China.

Kang, Y., Mao, G., Lu, C., He, L. (1995) Biological control of bacterial wilt of tomato by extracellular protein defective mutant of Pseudomonas solanacearum, Acta phytophysiologica Sinica 22: 287-288.

Katayama, K. and Kimura, S. (1987) Ecology and protection of bacterial wilt of potatosome control methods and their integration, Bull. Nagasaki Agriculture and Forest Export Station. 15: 29-57.
Kelaniyangoda, D.B. (1995) Identification of biovars of Ralstonia solanacearum in the upcountry of Sri Lanka. Tropical Agriculturist 150: $17-25$.

Kelaniyangoda, D.M., Salgadoe, A.S.A., Jayasekara, S.J.B.A., Banda, R.M.G. (2011) Wilting of bell pepper (Capsicum annum L.) causal organism isolation and a successful control approach, Asian Journal of Plant Pathology 5(4): 155-162.

Kelman, A. (1953) The bacterial wilt caused by Pseudomonas solanacearum, North Carolina Agricultural Export StationTechnical Bulletin 99: 194.

Kranz, J.H., Schmutterer, H., Kroch, W. (1997) Diseases, pests and weeds in tropical crops, John Wiley and sons, New York, 666 p.

Larkin, R.P., Fravel, D.R. (1998) Efficacy of various fungal and bacterial biocontrol organisms for control of fusarium wilt of tomato, Plant Diseases 82: 1022-1028.

Larkin, R.P., Fravel, D.R. (1999) Mechanisms of action and dose response relationships governing biological control of fusarium wilt of tomato by non-pathogenic Fusarium spp., Biological Control 89(12): 1152- 1161.

Lazarovits, G., Tenuta, M., Conn, K.L. (2000) Utilization of high nitrogen and swine manure amendments for control of soil borne diseases: Efficacy and mode of action, ISHS Acta Horticulturae, 532 p.

Lee, Jung-Myung, (1994) Cultivation of grafted vegetables I. Current status, grafting methods and benefits, Hort Science 29: 235239.

Loganathan M, Venkataravanappa V, Saha S, Sharma BK, Tirupathi S, Verma MK. (2013) Morphological, cultural and molecular characterizations of Fusarium wilt infecting tomato and chilli, Proceedings of National Symposium on Abiotic and Biotic Stress Management in Vegetable Crops, Indian Society of Vegetable Science, IIVR, Varanasi, $1214 \mathrm{p}$. 
Lopes, C.A., Boiteux, L.S. (2004) Biovar specific and broad spectrum sources of resistance to bacterial wilt (Ralstonia solanacearum) in Capsicum, Journal of Crop Breeding and Applied Biotechnology 4: 350355.

MacHardy, W.E., Beckman, C.H. (1981) Vascular wilt Fusaria: Infections and Pathogenesis. In: Fusarium: Diseases, Biology and Taxonomy, (eds) Nelson, P.E., Toussoun, T.A. and Cook, R.J., The Pennysylvania State University Press, University Park and London, pp. 365-390.

Maharaja, P., Vellaiyan, R., Ravikumar, M., Sivakumar, N. (2017) A comparative study on the effect of cow and buffalo dairy components in Capsicum annum and Eleuisine corocana, International Journal of Innovations in Agricultural Sciences 1(1): 21-25.

Naik, M.K. (2006) Wilt of chilli with special reference to cultural, morphological, molecular characterization and pathogenic variability of Fusarium isolates of India, Proceedings of Midterm Review Meeting of the Project held at Indian Institute of Vegetable Research, Varanasi.

Nejad, P., Johnson, P.A. (2000) Endophytic bacteria induce growth promotion and wilt disease suppression in oil seed rape and tomato, Biological Control 18: 208-215.

Nguyen, M.T., Ranamukhaarachchi, S.L. (2010) Soil borne antagonists for biological control of bacterial wilt disease caused by Ralstonia solanacearum in tomato and pepper, Journal of Plant Pathology 92(2): 395-405.

Oda, M. (1995) New grafting methods for fruit bearing vegetables in Japan, Japan Agriculture Research Quarterly 29: 187-194.

Park, M., Fernando, M. (1938) The relative resistance of some tomato varieties to bacterial wilt (Bacterium solanacearum F.F.Smith), Tropical Agriculture (Ceylon) 91: 333-337.

Persley, G.J. (1986) Bacterial wilt disease in Asia and the South Pacific, Proceedings of an international workshop held at PCARRD, Losbanos, Phillipines, 8-10 October 1985, p 145.

Peter, K.V., Gopalakrishnan, T.R., Rajan, S., Sadhan-Kumar, P.G. (1993) Breeding for resistance to bacterial wilt in tomato, eggplant and pepper. In: Hartman, G.L. and Hayward, A.C. (eds), Bacterial wilt, ACIAR Proceedings of the International Conference, Kaohsiung, pp 183-190.

Ragab, M.M.M., Ashour, A.M.A., Adel-Kader, M.M. (2012) In vitro evaluation of some fungicides alternatives against Fusarium oxysporum the causal of wilt disease of pepper (Capsicum annum L.), International Journal of Agriculture and Forestry 2(2): 7077.

Ristaino, J.B., Johnston, S.A. (1999) Ecologically based approaches to management of phytophthora blight on bell pepper, Plant Disease 83: 1080-1089.

Rivelli, V. C. (1989) A wilt of pepper incited by Fusarium oxysporum f. sp. capsici f. sp. nov. M.S. Thesis, Louisiana State University, Baton Rouge.

Sahi, I.Y., Khalid, A.N. (2007) In vitro biological control of Fusarium oxysporum causing wilt in Capsicum annum, Mycopathology 5(2): 85-88.

Sanogo, S. (2003) Chile pepper and the threat of wilt diseases. Plant Management Network. https://www.researchgate.net/publication/255 609877 Chile Pepper and The Threat of Wil t Diseases. Retrieved on 23rd January 2018.

Senarathna, U.N., Hettiarachchi, K., Thrikawala, S. (2012) Varietal evaluation of exotic tomato varieties in mid country wet zone, Annual Academic Sessions 2012, Open University of Sri Lanka, pp 29-32.

Senevirathne, S.N. De S. (1969) On the occurrence of Pseudomonas solanacearum in the hill country of Ceylon, Journal of Horticultural Science 44: 393-402.

Shafique, S., Asif, M., Shafique, S. (2015) Management of Fusarium oxysporum F. sp. capsici by leaf extracts of Eucalyptus 
citriodora, Pakistan Journal of Botany 47(3): 1177-1182.

Siemers, G.E. (1971) Methods of increasing the nutritive value of foods; An enrichment with vitamins and minerals. Nutritional evaluation of Food Processing. AVI Publishing Co. Westport.

Silveria, E.B., Da, R., Mariano, de, L.R., Michereff, S.J. (1995) Antagonism of Bacillus spp. against Pseudomonas solanacearum and effect on tomato seedling growth, Phytopathology 20: 605-612.

Singh, J.K., Kumar, M., Kumar, S., Kumar, A., Mehta, N. (2017) Inhibitory effect of botanicals on growth and sporulation of Fusarium oxysporum inciting wilt of chilli, Journal of Pharmacognosy and Phytochemistry 6(5): 2199-2204.

Skaggs, R., Decker, M., Van Leeuwen, D. (2000) A survey of southern New Mexico chile producers: Production practices and problems, New Mexico Agriculture and Experiment Station Technical Bulletin, 782 p.

Song, W., Zhou, L., Yang, C., Cao, X., Zhang, L., Liu, X. (2004) Tomato fusarium wilt and its chemical control strategies in a hydroponic system, Crop Protection 23: 243-247.

Srivastava, R., Khalid, A. Singh, U.S., Sharma, A.K. (2010) Evaluation of arbuscular mycorrhizal fungus fluorescent Pseudomonas and Trichoderma harzianum formulation against Fusarium oxysporum f. sp. lycopersici for the management of tomato wilt, Biological control 53: 24-31.

Suprapta, D.N., Khalimi, K. (2012) Antifungal activities of selected tropical plants from Bali island, Phytophamacology 2(2): 265-270.

Suryanto, D., Patonah, S., Munir, E. (2010) Control of fusarium wilt of chilli with chitinolytic bacteria, HAYATI Journal of Biosciences 17(1): 5-8.

Szczech, M.M. (1999) Suppressiveness of vermicompost against fusarium wilt of tomato, Journal of Phytopathology 147: 155161.

Takatsu, A., Lopes, C.A. (1997) Bacterial wilt in vegetables: scientific advances and control perspectives, Brazilian Horticulture 15: 170177.

Toyoda, H., Hashimoto, H., Utsumi, R., Kobayashi, H., Ouchi, S. (1988) Detoxification of fusaric acid by a fusaric acid resistant mutant of Pseudomonas solanacearum and its application to biological control of fusarium wilt of tomato, Phytopathology 78(10): 13071311.

Toyoda, H., Shimizu, K., Chatani, K., Kita, N., Matsuda, Y., Ouchi, S. (1989) Selection of bacterial wilt resistant tomato through tissue culture, Plant Cell Reports 8: 317-320.

Trigalet, A., Demery, D.T. (1990) Use of avirulent mutants of Pseudomonas solanacearum for the biological control of bacterial wilt of tomato plants, Physiological and molecular plant pathology 36:27-38.

Velupillai, M., Persely, G.J. (1986) Bacterial wilt disease in Asia and the South PacificBacterial wilt in Sri Lanka, ACIAR Proceedings 13: 57-64.

Vincent, V.M., Mew, T.W. (1998) Effect of a soil amendment on the survival of Ralstonia solanacearum in different soils, Phytopathology 88: 300-305.

Wang, J.F., Berke, T. (1997) Sources of resistance to bacterial wilt in Capsicum annuum, Bacterial wilt newsletter 14: 3-4.

Wang, J.F., Hanson, P., Barnes, J.A. (1998) Worldwide evaluation of an International set of resistance sources to bacterial wilt in tomato. pp. 269-270, Springer- Verlag Berlin Heidelberg.

Wang, J.F., Olivier, J., Thoquet, P., Mangin, B., Sauviac, L., Grimsley, N.H. (2000) Resistance of tomato line Hawaii 7996 to Ralstonia solanacearum Pss4 in Taiwan controlled mainly by a major strain specific locus, Molecular plant microbe interactions 13: 6-13. 